\title{
Pencegahan Paham Radikalisme Agama Di Tingkat Desa Melalui Penguatan Kader Muslimat Nahdlatul Ulama' Ranting Jarin
}

\author{
Dewi Pusparini ${ }^{*}$, Sri Wahyuni ${ }^{2}$, Muwaffiq Jufri ${ }^{3}$ \\ 1,2,3 Universitas Islam Madura, \\ Email : dewipusparini338@gmail.com¹, sriw29@gmail.com², muwaffiq.jufri@gmail.com³ \\ * Penulis Korespondensi: E-mail: dewipusparini338@gmail.com
}

\begin{abstract}
As mandated by Article 30 paragraph (1) of the 1945 Constitution of the Republic of Indonesia Year 1945, this activity is intended to synergize the strategic role of Muslimat $N U$ at the branch level in an effort to prevent religious radicalism. This activity trained the ability of Muslimat NU as a motivating cadre to prevent the spread of religious radicalism in order to: a) be able to teach and spread moderate and humanist Islam in the midst of people's lives. A qualified understanding of the moderation of Islam will be able to become a filter in preventing the spread of radical Islam. b) able to understand the types of radical Islamic groups, the ability to recognize this will facilitate Muslimat NU in detecting the presence of radical organizations around them. c) able to understand the methods of preventing the spread of radical Islam. This ability is very useful to free Jarin residents from radical religious-based notions. Muslimat NU ability to prevent the spread of religious radicalism will be optimized at the family level, given its role as the first madrasa will be able to prevent the spread of radical ideas in the family environment. In addition, further optimization will be directed to the surrounding community so that the existence of radical Islamic organizations in the village of Jarin has not developed.
\end{abstract}

Keywords: Muslimat NU, Prevention, Dissemination, Radicalism, Religion

\begin{abstract}
Abstrak
Sebagaimana amanat Pasal 30 ayat (1) UUD NRI 1945, kegiatan ini dimaksudkan untuk mensinergikan peran strategis Muslimat NU di tingkat Ranting dalam upaya mencegah radikalisme agama. Kegiatan ini melatih kemampuan Muslimat NU sebagai kader penggerak pencegahan penyebaran paham radikalisme agama agar: a) mampu mengajarkan dan menyebarkan paham Islam moderat dan humanis di tengah-tengah kehidupan masyarakat. Pemahaman yang mumpuni tentang moderasi Islam akan mampu menjadi filter dalam mencegah penyebaran paham Islam radikal. b) mampu memahami jenis-jenis kelompok Islam berpaham radikal, kemampuan mengenali ini akan memudahkan Muslimat NU dalam mendeteksi kehadiran organisasi radikal di sekitarnya. c) mampu memahami metode pencegahan penyebaran paham Islam radikal. Kemampuan ini sangat berguna untuk membebaskan warga Jarin dari paham-paham radikal berbasis agama. Kemampuan Muslimat NU dalam mencegah penyebaran paham radikalisme agama ini akan dioptimalkan pada tingkat keluarga, mengingat perannya sebagai madrasah pertama akan mampu mencegah penyebaran paham radikal di lingkungan keluarga. Di samping itu, optimalisasi selanjutnya akan diarahkan kepada masyarakat sekitar sehingga keberadaan organiasi Islam radikal di desa Jarin tidak mengalami perkembangan.
\end{abstract}

Kata kunci: Muslimat NU, pencegahan, penyebaran, radikal, agama. 


\section{PENDAHULUAN}

\section{Analisis Situasi}

Beberapa bulan terakhir kondisi keberagamaan di Indonesia mengalami ragam permasalahan, utamanya berkaitan dengan munculnya kembali aksi-aksi radikal dalam beragama. Kemunculan aksi-aksi tersebut ditandai oleh beberapa peristiwa kerusuhan bermotif agama serta peledakan bom di lokasi tertentu yang tersebar di beberapa wilayah di Indonesia. Beberapa perstiwa tersebut antara lain: Pertama, penyerangan terhadap jemaat geraja St. Widia Kabupaten Sleman Yogyakarta saat melakukan ibadah Misa Pagi pada tanggal 11 Februari 2018 (Okezone, 2018). Kedua, kerusuhan yang terjadi di Rumah Tahanan Markas Komando Brigadir Mobil (Rutan Mako Brimob) Bogor pada 10 Mei 2018 (Kompas, 2018). Ketiga, serangkaian bom bunuh diri yang terjadi di 3 (tiga) lokasi berbeda di Surabaya pada 13 Mei 2018. Lokasi tersebut ialah Gereja Katolik Santa Maria Tak Bercela di Jalan Ngagel Madya Utara, Surabaya. Gereja Pantekosta Pusat Surabaya di Jalan Arjuno. Gereja Kristen Indonesia di jalan Diponegoro (Tempo, 2018).

Ragam peristiwa tersebut memberikan pelajaran berharga bahwa gerakan dan paham radikalisme serta anarkisme agama masih menjadi ancaman serius dalam mewujudkan keamanan di negeri ini, utamanya terhadap usaha menciptakan hubungan yang harmonis, aman, dan damai antar umat beragama. Peristiwa ini juga memberikan beban baru bagi pemerintah dalam upayanya melaksanakan deradikalisasi yang harus menyasar semua kalangan masyarakat dengan ragam usia. Program deradikalisasi ini tidak cukup hanya dilaksanakan terhadap para narapidana terorisme di lembaga pemasyarakatan, tetapi juga harus menyentuh akar rumput masyarakat dengan fokus gerakan mulai dari penguatan pemahaman Islam yang ramah, hingga pada upaya menetralisasi paham keagamaan radikal yang sudah dianut.

Di ranah lokal Pamekasan, beberapa organisasi keagamaan berpaham radikal mulai mengalami perkembangan cukup signifikan. Ini ditandai dengan banyaknya umat muslim di Pamekasan menjadi anggota dan simpatisan beberapa organisasi keagamaan radikal, seperti Front Pembela Islam (FPI), Ar-roja', Aliansi Ulama' Madura (AUMA), dan bahkan Hizbut Tahrir Indonesia (HTI) dan lain sebagainya (Media Madura, 2018). Beragam aksi dilakukan seperti aksi mengutuk penganut sekte syi'ah, razia hotel dan rumah makan, serta kerusuhan lain yang berpotensi mengganggu stabilitas keamanan di Pamekasan (Rmol, 2018). Padahal, kegiatankegiatan tersebut bukan tugas organisasi keagamaan, tetapi telah menjadi tanggung jawab pemerintah serta aparatur kepolisian.

Kekhawatiranya ialah jika fakta penyebaran gerakan dan paham radikalisme agama sangat massif dilakukan kepada masyarakat pedesaan di Madura. Seperti yang terjadi di desa Jarin Kecamatan Pademawu Pamekasan, yang beberapa tahun terakhir bermunculan pahampaham keislaman baru bercorak radikal. Keberadaannya pun berhasil merekrut beberapa kader sebagai anggota. Adapun sebaran aliran keagamaan masyarakat desa Jarin sebagaimana tabel di bawah ini:

Tabel 1. Sebaran Paham Keagamaan Masyarakat Desa Jarin

\begin{tabular}{ccc}
\hline No & Jenis Organisasi Keagamaan & Jumlah Pengikut (Orang) \\
\hline 1 & Nahdlatul Ulama' & 3.527 \\
\hline
\end{tabular}




\begin{tabular}{clc}
\hline No & \multicolumn{1}{c}{ Jenis Organisasi Keagamaan } & Jumlah Pengikut (Orang) \\
\hline 2 & Front Pembela Islam & 72 \\
3 & Jama'ah Tabligh & 43 \\
4 & Aliansi Ulama Madura & 17 \\
5 & Wahidiyah & 13 \\
6 & Ar-roja' & 9 \\
7 & Hizbut Tahrir Indonesia & 7 \\
\hline & Total & $\mathbf{3 . 6 8 8}$ \\
\hline
\end{tabular}

(Sumber: Buku Desa Jarin tahun 2017)

Meskipun mayoritas masyarakat Jarin berafiliasi pada Nahdlatul Ulama' (NU), namun keberadaan aliran keagamaan berpaham radikal yang semakin banyak pengikutnya patut dijadikan rujukan sekaligus kekhawatiran akan massifnya gerakan radikalisme Islam di desa Jarin. Kekhawatiran ini disebabkan kultur keagamaan masyarakat Madura yang umumnya memiliki tipikal dan karakter tempramen serta begitu riskan pada isu keagamaan. Fanatisme orang Madura terhadap isu keagamaan begitu kuat dan rela melakukan kegiatan apapun demi memperjuangkan agamanya (Yuriadi, 2014: 669). Pemanfaatan kondisi ini oleh pegiat radikalisme akan mudah melahirkan tindakan anarkisme dengan dasar perintah agama. Fanatisme tersebut akan mendukung watak dan karakter masyarakat Madura yang identik dengan kekerasan sebagai identitas kulturalnya.

Dasar kekhawatiran di atas diperkuat pendapat Donald Black yang menjelaskan bahwa ada beberapa elemen penting yang mampu merubah perilaku hukum masyarakat, elemenelemen tersebut ialah: stratifikasi sosial, morphologi, organisasi, kontrol sosial, dan budaya, dengan model perubahan sebagaimana bagan di bawah ini:

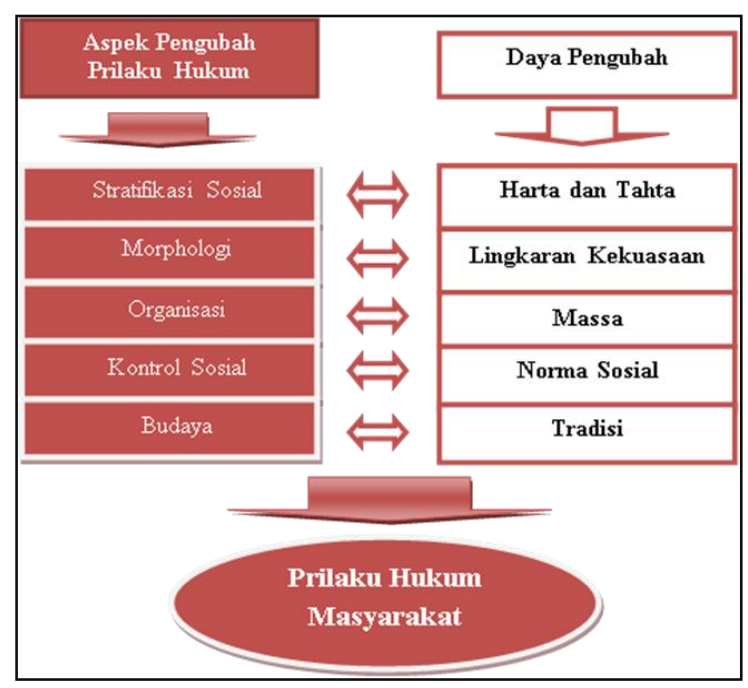

Gambar 1. Bagan Elemen Pengubah Prilaku Hukum Masyarakat

(Sumber: Disusun Penulis berdasarkan Buku The Behavior of Law)

Transformasi pandangan di atas akan melahirkan $2(\mathrm{dua})$ kemungkinan pola perubahan perilaku masyarakat menuju perilaku radikal dalam beragama di desa Jarin: Pertama, posisi organisasi termasuk salah-satu elemen penting yang mampu mengubah perilaku hukum 
masyarakat. Apabila organisasi keagamaan berpaham radikal mulai bermunculan dan diikuti oleh masyarakatnya, perilaku radikal masyarakat di desa Jarin dimungkinkan akan meningkat. Kedua, entitas budaya masyarakat Madura yang umumnya berkarakter tempramen dan mudah melakukan kekerasan, akan mudah dimanfaatkan dalam melakukan aksi-aksi radikal dalam beragama (Black, 1976: 86). Apalagi pola keberislaman masyarakatnya yang lebih menjurus pada fanatisme agama. Kedua pola perubahan perilaku ini dapat dilihat pada bagan di bawah ini.

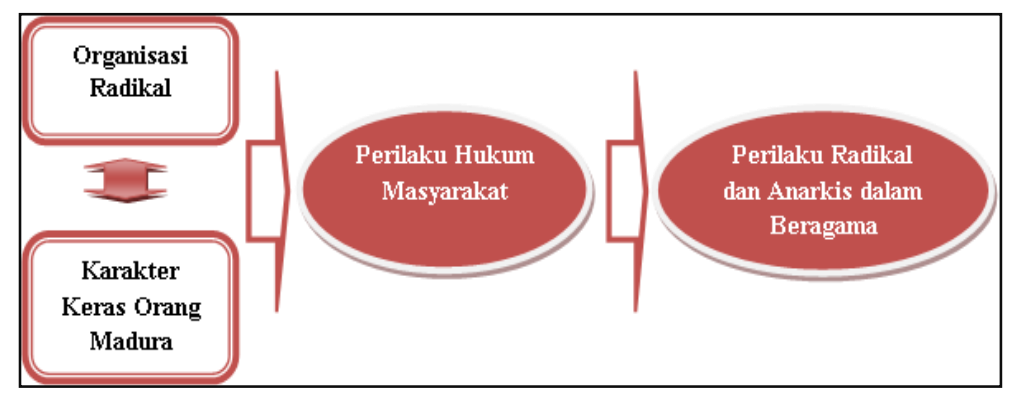

Gambar 2. Bagan Proses Berubahnya Prilaku Hukum Masyarakat yang Radikal

Sumber: Donald Black, hlm. 135.

Karenanya usaha menetralisasi paham keagamaan memang harus dilakukan sejak dini, demi mengantisipasi berkembangnya aliran-aliran dan organisasi Islam berpaham radikal di desa Jarin. Salah-satu upaya yang bisa dilakukan ialah dengan memanfaatkan peran strategis Muslimat Nahdlatu Ulama' (Muslimat NU) Ranting Jarin agar turut serta melakukan langkahlangkah pencegahan penyebaran paham radikalisme agama.

Strategisnya keberadaan organisasi ini didasarkan atas beberapa alasan, yakni: Pertama, keberadaan organisasi Muslimat NU di desa Jarin telah mengakar dan memiliki anggota fanatik. Artinya mayoritas kaum perempuan di desa Jarin memiliki hubungan ideologis dan emosional sehingga dapat dimanfaatkan untuk menetralisasi paham radikalisme agama, utamanya netralisasi di lingkungan keluarga; Kedua, Muslimat NU merupakan salah-satu organisasi yang secara konsisten menolak pemikiran radikalisme dalam beragama dengan menyuarakan gagasan Islam yang humanis dan mengupayakan hubungan harmonis antar umat beragama. Ketiga, Muslimat NU rutin menyelenggarakan kegiatan-kegiatan keislaman, baik berupa kajian mingguan ataupun pada peringatan acara-acara besar keagamaan lain yang memudahkan kaderisasi muslimat pencegah paham radikalisme agama. (Jazim Hamidi, 2016: 76).

Keberadaan Muslimat NU sebagai gerakan masyarakat sipil untuk mencegah dan menetralisasi paham keagamaan radikal di desa Jarin ini diilhami oleh gagasan akademis mengenai deradikalisasi paham radikalisme agama sebagaimana disampaikan oleh Muhammad A.S. Hikam. Menurutnya keberadaan masyarakat sipil dalam usaha radikalisasi begitu strategis, hal ini disebabkan oleh kuatnya kapasitas dalam hal sumber daya manusia, jejaring, serta kemampuan komunikasi langsung pada sasaran deradikalisasi. Hikam juga merekomendasikan kepada pemerintah dan pihak-pihak terkait agar memanfaatkan peran strategis ini agar cita untuk terbebas dari paham radikalisme agama dapat dicapai dengan baik (Hikam, 2016: 213).

Meski demikian terdapat beberapa persoalan serius dalam upaya melalui Muslimat NU ini, utamanya terhadap kecapakapan para aktivisnya dalam melakukan langkah-langkah 
pencegahan dan netralisasinya. Keberadaan SDM Muslimat NU yang rata-rata hanya berpendidikan di tingkat sekolah dasar menyebabkannya kurangnya penguasaan terhadap teknik dna strategi khusus dalam menangkal, mencegah, dan menetralisasi penyebaran paham radikalisme agama. Permasalahan ini juga yang menyebabkan tema kajian mingguan dan kegiatan keislaman lain pada Muslimat NU Ranting Jarin hanya berkaitan dengan kajian-kajian kutubiah seputar ubudiyah, syari'ah, dan aqidah.

\section{Permasalahan Mitra} antara lain:

Berdasarkan uraian pada analisis situasi di atas, permasalahan mitra pada proposal ini

a. Paham radikalime agama mulai semarak disebarkan dan mendapat banyak pengikut di desa Jarin.

b. Secara umum masyarakat desa Jarin merupakan tipikal masyarakat yang fanatik terhadap agama dan bertipikal tempramen dan keras dalam menyikapi isu keagamaan. Bila tidak memiliki cukup pengetahuan mengenai bahaya radikalisme agama, dikhawatirkan akan mudah dimanfaatkan dalam melakukan tindakan-tindakan anarkis.

c. Muslimat NU merupakan perkumpulan perempuan NU yang konsen di bidang penyebaran paham Islam humanis memiliki keterbatasan pengetahuan seputar startegi, metode, dan teknik dalam membendung, mencegah, dan menetralisasi paham radikalisme agama yang disebarkan di desa Jarin, utamanya berkaitan dengan strategi pencegahan di lingkungan keluarga.

\section{METODE PELAKSANAAN}

Untuk menanggulangi ragam permasalahan di atas, Fakultas Hukum serta Fakultas Keguruan dan Ilmu Pendidikan Universitas Islam Madura Pamekasan melaksanakan program kemitraan masyarakat dengan metode pendekatan berupa :

\section{Pelatihan penguatan pemahaman Muslimat NU tentang pentingnya ajaran Islam yang humanis dan moderat}

Poin utama pada pelaksanaan solusi ini ialah agar Muslimat NU dan masyarakat umum desa Jarin agar mampu memahami dan mngimplementasikan ajaran Islam yang mengedepankan usaha mencapai perdamaian dan kesejahteraan hidup umat manusia. Penguatan ini dimaksudkan agar masyarakat benar-benar memahami bahwa esensi Islam ialah untuk mewujudkan perdamaian dan menjunjung tinggi etika dalam beragama.

Kurangnya pengetahuan yang utuh berkaitan dengan esensi dan nilai humanisme Islam ini menyebabkan seseorang akan bersifat reaktif dalam menghadapi isu-isu keagamaan. Pola keberislaman seperti itu menyebabkan pemahamannya bersifat sempit dan jauh dai usaha menciptakan generasi emas muslim di bidang pengetahuan dan teknologi. Di samping itu, pola pemahaman yang demikian membuat keberadaan gerakan Islam konsen pada tindakantindakan kekerasan dalam beragama.

Solusi ini dimaksudkan untuk menciptakan tingkat kesadaran dan pengetahuan pemahaman Islam yang moderat bagi Muslimat NU dan masyarakat desa Jarin. Sebab salahsatu penyebab mudahnya penyebaran paham radikalisme agama diakibatkan oleh kurangnya pemahaman yang utuh mengenai peta aliran keislaman yang sangat beranekaragam corak ajaran dan kepentingan politiknya. Pemahaman tentang ragam aliran dalam islam berserta sejarah kelahiran dan arah gerakannya akan mampu meyakinkan muslimat NU terhadap pentingnya berislam dengan cara-cara yang damai, toleran, dan cinta keberagaman. 


\section{Pelatihan strategi Muslimat NU menghadapi massifnya penyebaran paham radikalisme agama}

Penting disampaikan bahwa selain negara, masyarakat sipil juga memiliki peran strategis dalam upaya menetralisasi dan mencegah penyebaran paham radikal di tengah kehidupan masyarakat. Sebagaimana pernah disampaikan oleh Muhammad A.S. Hikam, keberadaan gerakan masyarakat sipil ini sangat menentukan program deradikalisasi disebabkan keberadaanya langsung menyasar pada target deradikalisasi.

Untuk memaksimalkan gerakan tersebut, diupayakan optimalisasi peran strategis Muslimat NU dalam membendung dan menangkal penyebaran paham radikalisme agama di Desa Jarin. Pemilihan Muslimat NU sebagai pusat gerakan pencegahan paham radikalisme agama ini disebabkan oleh alasan-alasan rasional berupa:

a. Secara kultural Muslimat NU memiliki kedekatan dengan seluruh elemen masyarakat desa Jarin. Ini disebabkan karena secara kultur social dan tradisi keagamaan yang memang sama sebagai manusia yang sama-sama dilahirkan dari Rahim orang Madura.

b. Secara ideologis keagamaan, Muslimat NU memiliki kedekatan ideologi terhadap seluruh masyarakat desa Jarin yang mayoritas bermazhab syafi'iyah (pengikut ijtihad fiqh Imam syafi'ie) dengan pengamalan keagamaan yang berkiblat pada amaliyah-amaliyah dalam organisasi Nahdlatul Ulama', sebagai organisasi Islam yang banyak memiliki anggota di Madura, baik anggota secara structural ataupun kultural.

c. Muslimat NU ranting Jarin adalah kekuatan masyarakat sipil yang langsung berinteraksi dengan masyarakat desa Jarin dalam kehidupan kesehariannya. Kekuatan sipil merupakan kunci dari keberhasilan program pengentasan dan pembendungan paham dan/atau aliran radikalisme atas nama agama. Lemahnya kekuatan masyarakat sipil merupakan pintu awal dari semakin maraknya penyebaran ajaran Islam radikal.

Beragam keunggulan tersebut akan sangat bermanfaat dalam upaya menciptakan model pencegahan penyebaran paham radikalisme agama pada masyarakat pedesaan dengan mengoptimalkan kekuatan dan peran strategis Muslimat NU. Adapun tahapan utuh pelaksanaan PKMS ini dapat dilihat pada tabel bagan di bawah ini.

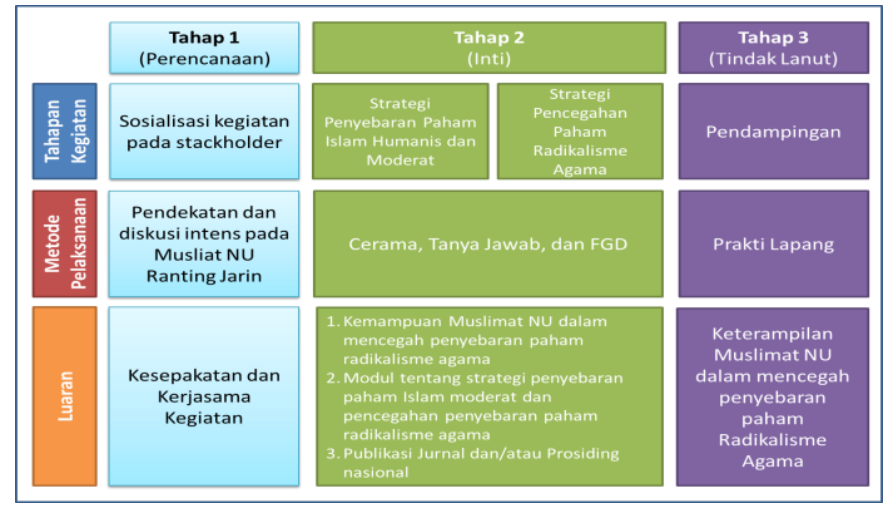

Gambar 3. Bagan Peta Pelaksanaan PKMS

(Sumber: Kreasi Penulis) 


\section{HASIL dan PEMBAHASAN}

Kegiatan yang sudah dilaksanakan dalam PKMS ini ialah :

\section{Sosialisasi Tujuan Program dan Penguatan Pemahaman tentang Bahaya Radikalisme Agama}

Salah-satu bentuk kegiatan pada PKMS ini ialah sosialisasi program kepada seluruh pengurus dan warga Muslimat Nahdlatul Ulama di Desa Jarin Kecamatan Pademawu Kabupaten Pamekasan. Maksud dari kegiatan ini ialah agar para pengurus dan seluruh anggota Muslimat NU paham bahwa keberadaan kegiatan ini sangat penting dilaksanakan mengingat perkembangan penyebaran paham radikalisme agama di Desa Jarin sudah semakin digalakkan. Ini dibuktikan dengan semakin banyaknya jumlah pengikut aliran-aliran Islam bernuansa radikal, gemar menilai tata peribadatan aliran yang lain salah, dan yang paling penting ialah untuk menghentikan ragam upaya yang menyebutkan bahwa sistem pemerintahan selain pemerintahan khilafah adalah salah.

Secara umum, untuk sekedar diketahui, bahwa Pamekasan merupakan salah-satu kabupaten yang ada di pulau Madura, Propinsi Jawa Timur. Di wilayah ini hampir semua penduduknya beragama Islam berasaskan ahlussunnah wal-jamaah dengan corak tradisioal keagamaannya. Karena itu keberadaan tempat-tempat pengajian dan perkumpulan keagamaan menjadi sangat penting bagi masyarakat. Umumnya masyarakat Madura menganggap bahwa tempat pengajian dan perkumpulan keagamaan selain sebagai tempat ibadah menuntuk ilmu, bermunajat bersama, dan bershalawat memohon syafaat Nabi Muhammad, juga merupakan tempat pokok untuk merumuskan solusi permasalahan sosial, budaya, politik bahkan ekonomi. Hal itu juga yang sudah mentradisi pada masyarakat Jarin yang juga mayoritas berpaham Islam Ahlussunnah Wal Jama'ah dengan corak dan karakter tradisionalisnya dalam beragama.

Akan tetapi beberapa tahun kemudian suatu perkumpulan dan pertemuan keagamaan di Desa Jarin dijadikan sebagai tempat untuk menyebarkan 'paham-paham Islam bercorak radikal dengan cara:

1. Mendatangi masjid-masjid dengan alasan memakmurkan dan menyemarakkan kegiatan keagamaan.

2. Menggelar kegiatan-kegiatan keagamaan dengan mengundang masyarakat umum dan diakhir acara ada kegiatan pendaftaran anggota kelompok aliran.

3. Mempengaruhi masyarakat umum dengan cara memberikan janji dimudahkan rizki, dilunaskan hutang, dan dijamin akan kaya dunia akhirat.

Ragam strategi perolehan anggota yang dilakukan oleh pegiat aliran Islam radikal tersebut tidak sepenuhnya disadari oleh masyarakat secara umum, terlebih cara-cara yang dilakukan memang terkesan sangat Islami dan berkesesuaian dengan tipikal keislaman orang Madura yang begitu riskan dengan isu-isu agama. Dalam tradisi kemaduraan, agama merupakan nilai tertinggi dalam pelaksanaan tata kehidupan kesehariannya masyarakatnya. Orang Madura secara umum memiliki fanatisme yang tinggi terhadap agama, karenanya mereka akan cenderung melakukan hal-hal apa saja yang dinilai akan bermartabat menurut ajaran agama yang dianutnya.

Secara umum, keberadaan fanatisme yang demikian memang dapat membawa pemeluknya pada tingkat keimanan yang hakiki dengan memilih jalan taqwa sebagai pondasi dalam segala aktifitas kesehariannya, baik aktivitas yang berkaitan dengan ubudiyyah ataupun yang berkaitan dengan muamalah. Tetapi, akan berbahaya manakala bentuk fanatisme yang demikian justru disalah-gunakan oleh pihak-pihak tertentu yang kemudian membuat watak dan corak keislaman masyarakat Madura menjadi radikal, keras, dan mudah menyalahkan 
antar sesama penganut agama Islam yang kebetulan berbeda pandangan berkaitan dengan konsep ajaran dan tradisi keagamaan.

Guna mengantisipasi hal tersebut terjadi, tim PKMS berisiniatif melakukan langkahlangkah kongkrit untuk membendung penyebaran paham radikalisme agama yang semakin kencang disebarkan oleh para pegiatnya. Langkah ini dimulai dengan tahapan sosialisasi pentingnya pemahaman Islam noderat, cinta damai, dan menghargai ragam perbedaan. Setidaknya terdapat dua tujuan dan materi yang disampaikan pada tahapan ini, antara lain:

a. Memberikan penjelasan terhadap pengurus Muslimat NU Ranting Jarin terhadap pentingnya kegiatan ini dalam rangka memudahkan tim PKMS dalam melaksanakan rencana kegiatan secara tuntas dan memiliki dampak yang signifikan terhadap usaha dalam membendung penyebaran paham radikalisme agama. Pertemuan ini juga menjelaskan seputar tahapantahapan kegiatan yang akan dilangsungkan oleh tim pelaksana PKMS. Penyampaiakan rencana program dimaksudkan untuk membangun sistem komunikasi dan menjalin keakraban antara tim PKMS dengan Pengurus Muslimat NU Ranting Jarin.

b. Memberikan penjelasan mengenai perkembangan penyebaran aliran Islam bernuansa radikalisme agama yang semakin meningkatkan kegiatannya dalam mempengaruhi masyarakat di Desa Jarin agar bersedia ikut bergabung dalam mengamalkan ajaran dan tradisi radikalismenya.

Pada pertemuan ini juga disampaikan mengenai motif-motif serta strategi untuk mendapatkan simpati masyarakat di Desa Jarin. Beberapa motif yang dimaksud antara lain ialah:

1. Mengadakan kajian ubudiyah yang bermaksud untuk meyakinkan masyarakat desa perihal amalan-amalan dan ajaran radikalnya bersumber dari kitab-kitab keislaman klasik. Biasanya, para pegiat radikalisme agama menggunakan kitab-kitab yang memang sesuai dengan pemahamannya, atau bahkan menggunakan kitab resmi mereka dalam setiap penggelaran pengajian dan pertemuan keagamaan lainnya.

2. Mengadakan program pemakmuran masjid yang lazim disebut sebagai "khuruj", kegiatan ini lumrahnya dilakukan oleh pegiat Islam Jama'ah yang memang menjadikan masjid sebagai basis gerakan. Biasanya pegiat aliran ini mendatangi masjid-masjid yang mereka anggap belum sesuai dengan fungsi masjid sebagaimana pemahaman ajarannya. Para pegiat aliran ini biasanya mendiami masjid dalam durasi yang cukup bervaroasi, mulai dari durasi dalam jangka 3 hari, 7 hari, hingga 14 hari, sesuai dengan tingkat ketidaksesuaian amalan-amalan masjid yang sedang didiami.

3. Menjanjikan suatu materi kepada target perekrutan anggota berupa dicukupkannya rizki dunia-akhiran manakala aktif dalam kegiatan mengamalkan ajaran-ajaran dan tradisi keislamannya. Bahkan ada beberapa yang terpaksa mengikuti ajarannya sebab dijanjikan akan dilunaskan segala hutang-hutangnya meskipun yang bersangkutan tidak bekerja. Dengan metode ini, beberapa diantara masyarakat Desa Jarin tertarik dan berbaiat untuk mengikuti aliran keislaman ini disebabkan oleh niatan untuk benar-benar terbebas dari hutang dan mendapatkan harta yang melimpah.

Beberapa metode penyebaran paham radikalisme berbasis agama di atas memang perlu disampaikan sejak dini terhadap para pengurus Muslimat Nahdlatul Ulama' sebagai antisipasi agar gerakan semacam di atas dapat dideteksi dini dan dipersempit ruang geraknya. Di samping itu, keberadaan Muslimat NU sebnarnya merupakan pengejewantahan dari organisasi induknya berupa Nahdlatul Ulama' (NU). NU merupakan organisasi keagamaan Islam (jami'iyah al-diniyyah al-Islamiyah) yang didirikan pada tanggal 31 Januari 1926 atau Rajab 1334 H, oleh para kyai pesantren (ulama) yang berhaluan ahlussunnah wal-jamaah, 
sebagai wadah mempersatukan diri, memelihara, melestarikan, mengemban, dan mengamalkan ajaran Islam 'alaa ahadil madzahibil arba'ah dalam rangka mewujudkan Islam sebagai rahmat bagi semesta yang lazim disebut sebagai agama yang rahmatan lil-'aalamin (Zuhairi, 2010: 285).

Keberagamaan NU didasarkan pada 3 (tiga) prinsip berupa tawassuth (moderat), tasamuh (toleran), dan tawazun (keseimbangan). Berdasarkan ketiga prinsip inilah NU meneguhkan misinya untuk mengakomodasi semua komunitas agama yang ada di Indonesia. Salah-satu contoh dari sikap NU yang demikian ialah saat mencuatnya usulan untuk membahas Ahmadiyah yang telah divonis sesat oleh Majelis Ulama Indonesia (MUI). Usulan tersebut kemudian dilakukan melalui rapat Pleno Pengurus Besar Nahdlatul Ulama (PBNU) pada September 2005 (Baso, 2006: 43).

Para tokoh NU yang tergabung dalam MUI dengan getol menyarankan agar NU memiliki sikap yang sama dengan MUI dan menyatakan Ahmadiyah sebagai aliran sesat dan menyesatkan. Namun, berkat dukungan KH. M. Achmad Sachal Mahfudz sebagai Rais 'Aam dan KH. Hasyim Muzadi sebagai Ketua Umum, pleno memutuskan bahwa NU berkomitmen untuk tidak memberikan label "sesat" terhadap komunitas Ahmadiyah. Dalam forum ini pula, NU kembali menegaskan komitmennya untuk melindungi berbagai komunitas keagamaan di Indonesia (Baso, 2006: 43). Dalam forum ini, NU hanya memberikan penjelasan bahwa Ahmadiyah merupakan ajaran di luar Islam. Pernyataan tersebut tentu lebih bijaksana dibanding memberikan label "sesat" terhadap Ahmadiyah, dan merupakan bukti bahwa NU menghargai, menghormati, dan melindungi hak-hak yang dimiliki oleh para penganut ajaran Ahmadiyah dalam meyakini dan menjalankan peribadatan agamanya (Febriando, 2014: 117).

\section{Pelatihan Pencegahan Penyebaran Paham Radikalisme Agama Melalui Peran Strategis Muslimat NU di Tingkat Ranting.}

Sebagaimana yang telah disampaikan di atas mengenai keberadaan Muslimat NU dengan komitmennya dalam mewujudkan tatanan keberislaman yang moderat dan menghargai perbedaan, pada kegiatan ini dilaksanakan suatu pelatihan dalam rangka memaksimalkan peran Musaimat NU dalam membumikan ajaran islam humanis sekaligus memberikan pembekalan pada seluruh anggotanya dalam upaya mencegah penyebaran ajaranajaran Islam bernuansa radikal.

Pada kegiatan ini, tim PKMS memulai kegiatan dengan tahapan-tahapan penyampaian materi antara lain:

\section{a. Sebab-sebab mudahnya penyebaran aliran keagamaan radikal.}

Pada sesi ini, disampaikan bahwa keberadaan aliran keagamaan radikal dapat diterima oleh masyarakat pedesaan disebabkan oleh beberapa hal, antara lain (Munip, 2012: 160-175).

1. Memiliki tingkat pemahaman terhadap ajaran dan teks keagamaan yang kurang tuntas, tekstual, dan sistem memahami dalil yang sepotong-potong.

2. Pemahaman yang kurang tuntas berkaitan dengan sejarah awal umat Islam hingga tersebarnya Islam di Indonesia. Keadaan tersebut kemudian diperparah oleh tindakan pengkombinasian dengan idealisasi beragama yang berlebihan dan tidak menempatkan konteks sejarah pada tempat dan waktu yang semestinya. Fenomena ini Nampak secara umum pada pandangan keagamaan ala gerakan salafi, terlebih lagi dalam spektrum sangat fundamentalis radikal seperti wahabiyah yang muncul di semenjanjung Arabia pada akhir abad ke 18 awal sampe pada abad 19 dan terus menyebar hingga ke Indonesia hingga saat ini, dengan "jualan pokok" berupa gerakan pemurnian ajaran Islam, suatu gerakan yang diyakini sebagai usaha untuk membersihkan aqidah dan ajaran Islam dari pemahaman dan 
praktek keagamaan yang mereka pandang sebagai bid'ah, syirik, dan takhayyul yang tidak jarang dilakukan dengan cara kekerasan.

3. Fenomena deprivasi politik, sosial dan ekonomi yang masih bertahan dalam masyarakat Indonesia yang cenderungn komunal yang umumnya cenderung kagum pada pihak-pihak tertentu yang dianggap kharismatik. Pola keberagamaan yang demikian kemudian dijadikan kesempatan untuk mengkultuskan seorang yang dianggap kharismatik sebagai tokoh pentolan dalam penyebaran ajaran radikal. Pada saat yang bersamaan, disorientasi dan dislokasi sosial budaya dan ekses globalisasi, dan semacamnya sekaligus merupakan tambahan faktor-faktor penting bagi kemunculan kelompok-kelompok radikal. Kelompokkelompok ini dengan dogma eskatologis tertentu bahkan memandang dunia sudah menjelang akhir zaman dan kiamat, dan juga beranggapan sudah waktunya bertaubat dan segera kembali pada ajaran kemurnian islam. Kegiatan ini dilakukan melalui pemimpin dan kelompok mereka.

4. Merebaknya ajaran, doktrin, dan pandangan teologis-eskatologis konflik sosial yang seakan memberikan kebolehan dalam melakukan tindakan-tindakan berupa kekerasan bernuansa intra dan antar agama. Bahkan doktrin yang demikian juga memberikan kebolehan terhadap konflik antar agama dengan Negara.

5. Masih adanya konflik-konflik dan sengketa sosial berlandaskan alasan-alasan keagamaan, baik yang bersandarkan pada persoalan aqidah hingga muamalah. Bahkan beberapa diantaranya masih juga ada konflik yang diakibatkan oleh perbedaan paham keagamaan (ekstra). Fenomena ini merupakan imbas dari reformasi yang semakin tidak terkendali yang membebaskan seluruh paham keagamaan dengan mudah mengembangkan ajarannya, termasuk aliran yang bernuansa radikal. Secara lebih terperinci, fenomena tersebut disebabkan oleh; a) Euphoria atas kebebasan atas hak-hak yang diberikan Negara pasca reformasi yang tidak peduli dengan pihak-pihak lain sebagai pemilik hak-hak lainnya. Keadaan yang demikian berdampak pada merosotnya paham toleransi akibat masingmasing orang lebih terfokus pada pemenuhan hak-hak pribadinya, termasuk hak dalam beragama; b) Masih dianutnya fragmentasi politik dan sosial khususnya di kalangan elite politik, sosial, milier, yang terus mengimbas ke lapisan bawah dan menimbulkan konflik horizontal yang laten dan luas. Terdapat beberapa indikasi, konflik, kekerasan bernuansa agama bahkan diprovokasi kalangan elit tertentu untuk kepentingan mereka sendiri: c) Penegakan hokum yang cenderung tidak konsisten dalam menyelesaikan kasus-kasus yang berkaitan dengan konflik-konflik keagamaan, baik yang skalanya antar intra agama, ataupun konflik dengan skala ekstra agama (agama yang berbeda), yang memang dimotori oleh kontestasi kelompok-kelompok elit local; d) Meluasnya disorientasi dan dislokasi dalam cara pandang kehidupan masyarakat Indonesia diakibatkan oleh kesulitan hidup, kemiskinan, kesenjangan sosial, yang menyebabkan mudahnya disulut emosi utamanya emosi-emosi yang berkaitan dengan basis keagamaan.

6. Proses pembelajaran teori dan ajaran-ajaran keagamaan yang sporadis tanpa melalui sumber-sumber otoritatif yang dapat dipertanggungjawabkan secara kaidah keagamaan. Banyak dari kalangan masayarakat Indonesia yang cenderung belajar melalui media internet dan media digital lainnya. Padahal, selain menggunakan menggunakan media kertas seperti surat kabar, buletin, majalah, dan lain sebagainya, kelompok-kelompok radikal tersebut sangat memanfaatkan dunia maya untuk menyebarkan buku-buku dan informasi mengenai ajaran-ajaran radikalnya. 


\section{b. Metode Pencegahan Penyebaran Paham Radikalisme Agama Melalui Peran Strategis Muslimat Nahdlatul Ulama di Tingkat Desa.}

Pada dasarnya, Pasal 30 ayat (1) UUD NRI 1945 memberikan pengaturan terkait keberadaan warga negara yang dihimbau untuk terlibat aktif dalam upaya memperkuat keamanan dan pertahanan bangsa Indonesia. Keberadaan masing-masing warga negara sangat diakui oleh negara untuk memperkuat dan membantu aparatur negara dalam upaya menjaga kedaulatan, keamanan, dan pertahanan agar semangat kesatuan dalam bingkai Negara Kesatuan Republik Indonesia dapat dijaga dan dijamin keberlangsungannya.

Harapan awal kegiatan ini ialah tidak hanya berhenti pada satu tahun kegiatan, tetapi bisa dilaksanakan secara berkesinambungan oleh mitra sampai terwujudnya cita-cita optimalisasi peran strategis Muslimat NU dalam mencegah penyebaran paham radikalisme agama di desa Jarin. Tahap pertama yang hendak diwujudkan ialah kesadaran Muslimat NU dan masyarakat desa Jarin terhadap pentingnya paham Islam moderat dan bahaya gerakan radikalisme dalam beragama. Sedangkan tahapan berikutnya ialah memastikan kemampuan Muslimat NU dalam membendung dan mencegah penyebaran paham radikalisme, fundamentalisme, dan anarkisme agama di Desa Jarin.

Untuk mewujudkan cita di atas, kegiatan dan/atau metode yang akan dirancang ialah:

1. Pelatihan dengan teknik training for trainer kepada Muslimat NU terkait metode sosialisasi dan pengajaran pemahaman Islam moderat dan humanis serta strategi pencegahan penyebaran paham radikalisme agama.

Pelatihan ini dimaksudkan untuk meningkatkan pengetahuan dan kemampuan anggota Muslimat NU Ranting Jarin sebagai agen penyebar ajaran Islam ahlussunah Wal-jamaah yang berorentasi pada pelaksanaan ajaran Islam yang moderat, toleran, dan mengupayakan hubungan yang harmonis antar umat beragama. Pelatihan ini juga akan bermanfaat dalam memberikan pemahaman pada Muslimat NU untuk bisa mendeteksi secara dini penyebaran paham radikalisme agama. Deteksi secara dini akan memudahkan langkah-langkah muslimat NU dan beberapa pihak terkait dalam koordinasi pencegahan dan netralisasi paham radikalisme agama.

Dengan pelatihan ini diharapkan perkumpulan Muslimat NU Ranting Jarin bisa dijadikan sebagai pelopor gerakan pencegahan paham radikalisme agama berbasis kekuatan masyarakat sipil, dengan sasaran utama:

\section{a. Internal keluarga muslimat}

Langkah pertama sosialisasi paham Islam humanis dan moderat ini dilakukan pada tingkat keluarga (Ervi, 2017: 37). Pelatihan ini untuk meningkatkan kemampuan muslimat dalam berintegrasi dengan kelurga dalam rangka menyebarkan ajaran Islam yang rahmah. Keberadaan Muslimat NU sebenarnya memiliki peran strategis dalam upaya menguatkan paham Islam rahmah di keluarga. Utamanya peran sentralnya sebagai madrasah pertama bagi anak-anaknya agar tidak mudah menerima ajaran-ajaran islam yang berorientasi pada paham radikalisme dan tindakan anarkisme dalam beragama.

Langkah ini penting dilakukan mengingat dalam beberapa kasus radikalisme agama, terdapat satu anggota keluarga yang menjadi pelaku dalam pengeboman beberapa rumah ibadan di Surabaya pada tanggal 13 Mei 2018. Peristiwa ini menunjukkan bahwa saat ini paham radikalisme agama justru sangat mudah disebarkan di tingkat keluarga. Karenanya menjadi penting langkah penguatan paham Islam humanis dan moderat di tingkat keluarga ini dilakukan agar keberadaan keluarga dan rumah tangga di desa Jarin dapat dibentengi dari kemungkinan masuknya akses ajaran paham radikalisme agama. 


\section{b. Masyarakat sekitar}

Sebagaimana pernah disampaikan oleh Muhammad AS Hikam dalam bukunya berjudul "Deradikalisasi", bahwa keberadaan masyarakat sipil dalam upaya deradikalisasi dan netralisasi paham radikalisme agama begitu strategis. Ini disebabkan karena masyarakat sipil ialah elemen yang secara langsung memiliki kedekatan hubungan antara sasaran deradikalisasi. Selain itu keberadaan masyarakat sipil memiliki kapasitas dalam hal sumber daya manusia, jejaring, serta kemampuan komunikasi langsung pada sasaran deradikalisasi. Kemampuan dan kapasitas inilah yang tidak dimiliki oleh aparatur negara dalam memberantas paham radikal. Kegiatan ini dimaksudkan untuk mengimplementasikan gagasan tersebut dengan memaksimalkan peran strategis Muslimat NU yang secara kultural dan ideologis memiliki kedekatan dan tingkat komunikasi yang inten bagi masyarakat desa Jarin. Dengan kapasitas yang demikian maka usaha membendung penyebaran radikalisme agama di desa Jarin akan mudah dilaksanakan dengan baik.

Pada pelaksanaannya, Tim PKMS memberikan penekanan kepada seluruh pengurus Muslimat NU di Desa Jarin terhadap peran strategisnya dalam upaya membendung penyebaran paham Islam yang cenderung mengarah pada ajaran kekerasan atas nama agama dan menganggap ajaran di luar paham keagamaanya tidak benar. Paham yang bercorak demikian semestinya segera diantisipasi lebih dini dengan memaksimalkan kekuatan dan kekompakan Muslimat NU sebagai basis kekuatan sipil yang dimiliki oleh masyarakat di Desa Jarin. Optimalisasi potensi yang sedemikian besar dipercaya akan menyulitkan gerakan penyebaran aliran Islam Radikal di Desa Jarin.

Secara sederhana kegiatan yang akan dilakukan pada pelatihan ini sebagaimana uraian tabel di bawah ini:

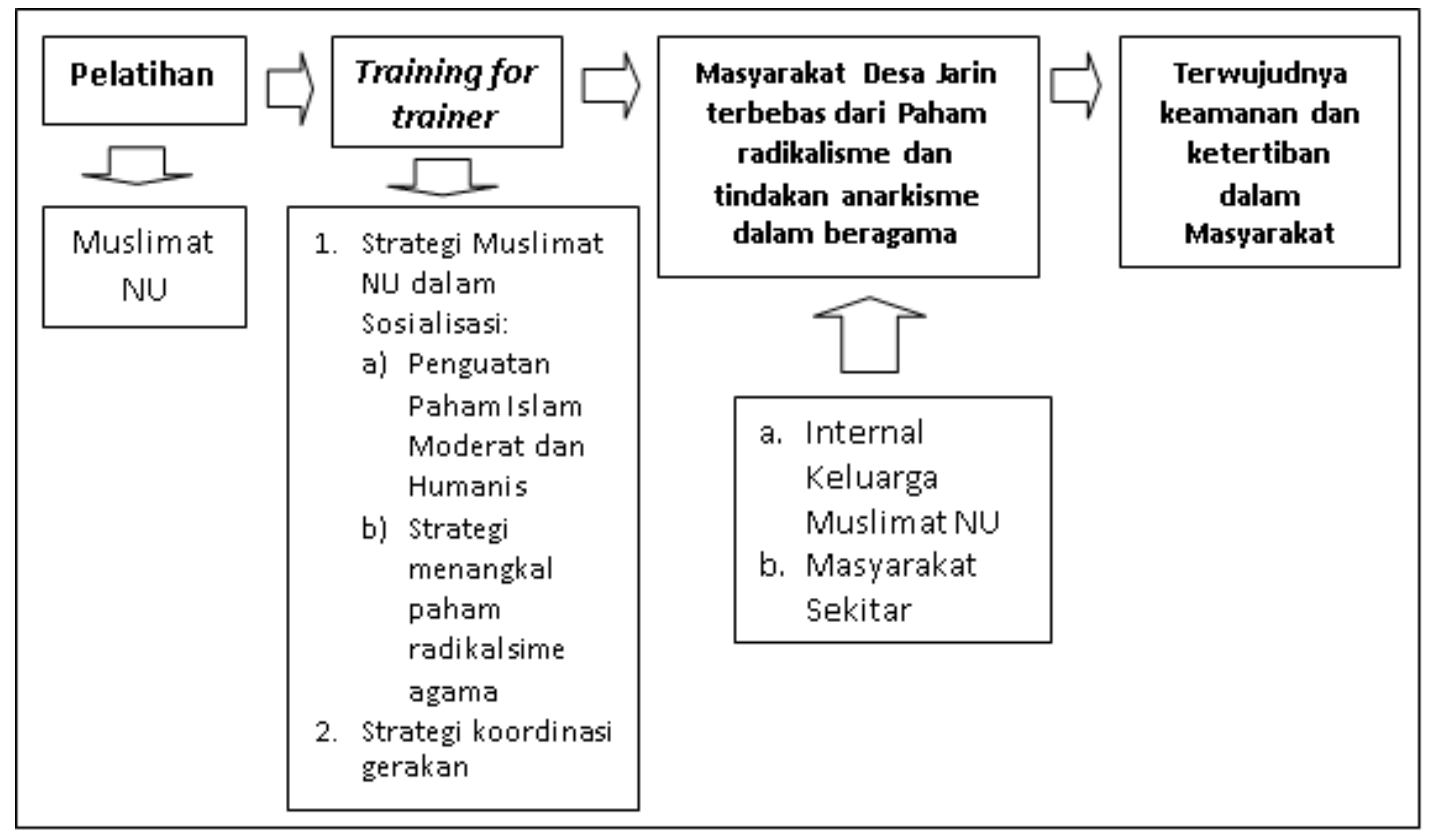

Gambar 4. Peta Pelatihan Penguatan Islam Moderat dan Strategi Pencegahan Paham Radikal (Sumber : Kreasi Penulis) 


\section{KESIMPULAN}

Peran strategis Muslimat Nahdlatul Ulama' ranting Jarin dalam upaya membendung penyebaran ajaran radikalisme agama diyakini oleh keberadaannya sebagai suatu kekuatan masyarakat sipil dimana yang bersangkutan memiliki modal utama seperti: 1) sebagai organisasi keislaman terbesar yang dianut oleh mayoritas masyarakat di Desa Jarin; 2) Ajaran dan pola gerakan Muslimat NU yang berlandaskan faham Islam moderat berwawasan ahlussunan wal-jama'ah sehingga membuat keberadaannya lebih cenderung ramah dan damai dalam menghargai perbedaan pandangan dalam beragama, terlebih ajaran-ajaran yang selama ini diperjuangkan NU ialah ajaran yang mencintai perdamaian, kekeluargaan, dan cinta tanah air. Dengan pola ajaran yang demikian, sangat sulit ditemukan prilaku-prilaku radikal di lingkungan pengikut organisasi ini, karena memang ajaran damai dan sikap toleran merupakan entry point dari ajaran yang dikembangkan oleh NU. Keberadaan posisi strategis yang demikian harus dioptimalkan dalam rangka melakukan pembendungan terhadap penyebaran aliran Islam Radikal yang kini mulai dilakukan di Desa Jarin.

\section{DAFTAR PUSTAKA}

Ahmad Baso, 2006, NU Studies; Pergolakan Pemikiran Antara Fundamentalisme Islam dan Fundamentalisme Neo-Liberal, Jakarta: Erlangga,.

Donald Black, 1976, The Behavior Of Law, New York: Academic Press.

Doni Febriando, 2014, Kembali Menjadi Manusia, Jakarta: Elex Media Komputindo.

Ervi Siti Zahroh Zidni, 2018, “Kemitraan Keluarga dalam Menangkal Radikalisme”, Jurnal Studi Al-Qur'an, Vol. 14, No. 1.

Jazim Hamidi, Muhammad Dahlan, Muwaffiq Jufri, 2016, "Penyelesaian Konflik antar Aliran Agama Prespektif Kearifan Lokal; Studi Kasus di Madura", Laporan Hasil Penelitian P3M Fakultas Hukum Universitas Brawijaya, Malang.

Kompas, "Sedang Misa, Pastor dan Umat Gereja Santa Lidwina Bedog Sleman Diserang", https://regional.kompas.com/read/2018/02/11/10104641/sedang-misa-pastordan-umat-gereja-santa-lidwina-bedog-sleman-diserang, diakses pada 1 Juni 2018.

Media Madura, "ASN Hingga Politisi di Pamekasan Terdata Anggota dan Simpatisan HTI", https://mediamadura.com/asn-hingga-politisi-di-pamekasan-terdata-anggota-dansimpatisan-hti, diakses pada 23 Juni 2018.

Muhammad A.S. Hikam, 2016, Deradikalisasi; Peran Masyarakat Sipil Indonesia Membendung Radikalisme, Jakarta: Penerbit Buku Kompas.

Okezone, "Fakta-Fakta Dibalik Kerusuhan Mako Brimob yang Tewaskan 5 Polisi", https://news.okezone.com/read/2018/05/12/337/1897392/fakta-fakta-di-balikkerusuhan-mako-brimob-yang-tewaskan-5-polisi, diakses pada 4 Juni 2018.

Rindha Widyaningsih, 2018, "Kerentanan Radikalisme Agama di Kalangan Anak Muda", Prosiding Seminar Nasional dan Call for Papers "Pengembangan Sumber Daya Perdesaan dan Kearifan Lokal Berkelanjutan VII"17.

Rmol, "Setara Institute: Sweeping FPI di Pamekasan Brutal dan Melawan Hukum", https://hukum.rmol.co/read/2018/01/23/323637/Setara-Institute:-Sweeping-FPIDi-Pamekasan-Brutal-Dan-Melawan-Hukum- diakses pada 23 Juni 2018. 
Tempo, "Ledakan Bom di Surabaya Terjadi di Tiga Gereja", https://nasional.tempo.co/read/1088304/-ledakan-bom-di-surabaya-terjadi-di-tigagereja, diakses pada 12 Juni 2018.

Yuriadi, 2014, Carok dan Harga Diri Masyarakat Madura Dalam Prespektif Psikologi. Prosiding Seminar Nasional Budaya Madura; "Madura Dalam Kacamata Sosial, Budaya, Ekonomi, Agama, Kebahasaan, dan Pertanian". Puslit Budaya dan Potensi Madura LPPM Universitas Trunojoyo Madura.

Zuhairi Misrawi, 2010, Hadratussyaikh Hasyim Asy'ari; Moderasi, Keumatan, dan Kebangsaan, Jakarta: Penerbit Buku Kompas. 